Article

\title{
Cursus Honorum: Personal Background, Careers and Experience of Political Leaders in Democracy and Dictatorship-New Data and Analyses
}

\author{
Alexander Baturo \\ School of Law and Government, Dublin City University, 9 Dublin, Ireland; E-Mail: alex.baturo@dcu.ie
}

Submitted: 29 February 2016 | Accepted: 9 May 2016 | Published: 23 June 2016

\begin{abstract}
Politics in democracy and dictatorship is markedly different; democracy and dictatorship are also associated with distinct policy outcomes. Do political regimes also select different leaders, i.e., do democratic leaders have distinct personal backgrounds to those of their peers in dictatorships, do they tend to hold different prior careers and posts while climbing the "greasy pole" of politics? The aim of this paper is to introduce the new data on leaders' careers in democracy and dictatorship and compare their personal background, experience in politics, careers and significant posts prior to their tenure, and details about their time in office, inter alia. In general, democratic leaders differ from nondemocratic ones in terms of their educational, social and career background. The paper also finds significant differences among leaders in different nondemocratic regimes, and suggests possible venues for further research.
\end{abstract}

\section{Keywords}

comparative democratisation; democracy and dictatorship; new dataset; personal background; political leaders

\section{Issue}

This article is part of the issue "New Approaches to Political Leadership", edited by Mark Bennister (Canterbury Christ Church University, UK).

(C) 2016 by the author; licensee Cogitatio (Lisbon, Portugal). This article is licensed under a Creative Commons Attribution 4.0 International License (CC BY).

\section{Introduction}

Scholars have long investigated the effects of democratic and nondemocratic institutions on leaders' behaviour in office, the probability of and manner of exit from that office, particularly during and after military conflict (e.g., Bueno de Mesquita, Smith, Siverson, \& Morrow, 2003; Escribà-Folch \& Wright, 2015; Goemans, 2008; Svolik, 2012; Weeks, 2012). Such studies have often relied on the pioneering data set on political leaders, Archigos, that included general details about leaders' time in office, exit and fate (Goemans, Gleditsch, \& Chiozza, 2009). Alongside research that looked at the effects of institutions on leaders, studies equally exist that examine the effects of leaders and their personal traits. Because such studies require more detailed information about leaders' personal background which is not covered by the Archigos, the majority of scholars have to undergo their own significant data-collection efforts pertaining to some aspect of leaders' personal background and traits. As a result, the new wave of leadership studies in political science and economics is extremely data-intensive (e.g., Alexiadou, 2015; Baturo, 2014; Besley \& Reynal-Querol, 2011; Byman \& Pollack, 2001; Colgan, 2013; Dreher, Lein, Lamla, \& Somogyi, 2009; Hayo \& Neumeier, 2014; Horowitz \& Stam, 2014; McDermott, 2007). While several new cross-national data sets have emerged that are able to account for various aspects of leaders' background and traits (e.g., Dreher et al., 2009; Ellis, Horowitz \& Stam, 2015; Gerring, Oncel, Morrison, \& Keefer, 2014; Ludwig, 2002), the majority of leadership studies focus, and provide data on, very specific aspects of leaders' personal background (e.g., Besley \& Reynal-Querol, 2011; Byman \& Pollack, 2001; Horowitz \& Stam, 2014); many only cover particular geographic regions or political regimes, e.g., only democracies or presidential regimes (e.g., Alexiadou, 2015; Baturo, 2014; Pérez-Liñán, 2009).

The aim of this paper is twofold. First, it introduces 
new cross-national data that makes a significant contribution to our knowledge about leaders, in particular providing very detailed information about their careers, experience, and prior posts. Second, it provides detailed comparisons of leaders in democracy and dictatorship, as well as of leaders across different nondemocratic regimes. The title of the new data set, Cursus Honorum, i.e., career ladder in Latin, is chosen partly to honour the groundbreaking Archigos dataset on political leaders developed by Goemans et al. (2009) in which Archigos is the Greek term for ruler. However, the term Cursus Honorum, apart from its similar connotations to antiquity, also neatly describes the key aspects of the data that distinguish it from other data sources on political leaders. In particular, Cursus Honorum accounts for various aspects of political careers of leaders over long periods of time prior to assuming political office and even after. ${ }^{1}$ The data set includes certain biographical details about leaders, their background, education, and professional experiences that the existing datasets on national political leaders also include albeit often for different country samples or other time periods (e.g., Alexiadou, 2015; Besley \& Reynal-Querol, 2011; Dreher et al., 2009; Ellis et al., 2015; Ludwig, 2002). The Cursus Honorum, however, offers much more detailed data on educational attainment, prior political posts and political experience, details about time in office and post-tenure occupations. Also, the data set extends the coverage from 2004the Archigos covers until the end of 2004-to 2010.

The second aim is to compare the backgrounds and careers of political leaders in democracy and dictatorship. The systematic analysis of leaders' distinct careers and traits will enhance our understanding of elite politics and recruitment and how distinct political regimes operate. Therefore, having introduced the new data in the section below, the section that follows compares leaders in democracy and dictatorship in terms of their general and family background, education, prior careers and posts, as well as experience. In brief, democratic leaders are better educated, more likely to have law and economics degrees, and tend to hold more significant political posts prior to office. I also examine leaders across different nondemocratic regimes and find that leaders in military regimes are more likely to have middle-class family backgrounds than those in

\footnotetext{
${ }^{1}$ Goodman (1997, p. 23) refers to cursus honorum as "the rigid hierarchy of the cursus honorum, the steps by which a man advanced to the peak of a political career, the consulship, or, for a select few, appointment as one of the two censors." Furthermore, cursus honorum continued even after the Romans attained the supreme magistracies: "The true glory of senatorial life, then, lay in the magistracies for which senators alone were eligible....[T]he proconsulship of Asia or Africa retained the highest esteem and became the acme of the senatorial cursus. By tradition, only the most senior ex-consuls were nominated for Africa and Asia" (Goodman, 1997, p. 168).
}

other regime types. At the same time, leaders in party regimes, in terms of their careers and experience, have more in common with democratic leaders than with other dictators. In the final section, I briefly review the scholarship on leaders and discuss possible empirical applications of the new data including the analyses of linkages between particular careers and policies in office or the effects of political experience on policymaking and survival in office, among other things.

\section{An Overview of the Cursus Honorum Data}

In addition to the Archigos data (Goemans et al., 2009) discussed above, other datasets about political leaders exist and will almost certainly appear in the future. ${ }^{2}$ Dreher et al. (2009), Besley and Reynal-Querol (2011) and Ellis et al. (2015) also collected data on various aspects of the personal background of political leaders. Ellis et al. (2015) focus mainly on military aspects of the personal background of leaders from 1875-2004, however, their data also include other important aspects such as leaders' family and educational details. In turn, Dreher et al. (2009) examine the impact of the individual background of 500 political leaders from 73 countries on economic reform from 1970-2002. ${ }^{3}$ Likewise, Besley and Reynal-Querol (2011) include variables on the educational attainment of leaders from 18722004, following the eight-way classification of Ludwig (2002). In turn, Gerring et al. (2014) cover not only contemporaneous leaders but also those in the top echeIon of political elites.

Inevitably, the Cursus Honorum data set introduced herein shares several indicators with existing datasets. However, the Cursus Honorum offers new variables, especially those related to specific details of leaders' political career paths. The data include more than 50 various indicators pertaining to personal background, such as previous career and significant posts prior to assuming office, number of years in formal politics, educational background, whether they were ever jailed, the military rank of current or former military officers, indicators pertaining to their time in office and entry and exit from that office, as well as post-leadership career. Several variables from the data set first appeared

\footnotetext{
2 Arguably, with a notable exception of a cross-national study by Bienen and van de Walle (1991) or several studies of personal characteristics, recruitment and careers of political elites in Western democracies (Eulau \& Czudnowski, 1972; Putnam, 1973), the majority of earlier studies generally did not rely on, nor introduce new empirical data about leaders (e.g., Blondel, 1987).

${ }^{3}$ It appears that political scientists and economists study similar phenomena in isolation: Dreher et al. (2009, p. 171) acknowledged that they collated the list of leaders independently without prior knowledge of the existing Archigos dataset which has long been a standard in political science (Goemans et al., 2009).
} 
in Baturo (2014). The Cursus Honorum data set covers 1,501 political leaders in office from the 1960-2010 period, including interim leaders, in all countries (except small island nations), in democratic and nondemocratic regimes. ${ }^{4}$

In general, Cursus Honorum variables may be divided into several groups, as seen from Table 1 . First, the data include general information about leaders such as the name of the effective chief political executive and time in office. ${ }^{5}$ Likewise, the data include common

${ }^{4}$ The Cursus Honorum data were mainly collected from 200910 (updated in 2012-14), apart from Archigos at that time I was not familiar with the existing large-n datasets on rulers' personal background. The sources used include country political histories, leaders' biographies, reference works, government websites, newspaper archives, book references, such as Bienen and van de Walle (1991) or Lentz (1994), as well as web references, such as www.rulers.org, www.worldstatesmen.com, Zarate (2011). For example, political biographies of Swiss leaders were sourced from Historical Dictionary, http://www.hls-dhsdss.ch/. The indicators vary in their reliability, e.g., political career or prior political post are generally reliable because such facts are usually reported by the majority of bibliographic sources and are not subject to interpretation. In case of other variables, such as number of years in formal politics, a certain degree of subjectivity is unavoidable.

5 If the same individual assumes office again in non-consecutive country identifiers and leaders' age. ${ }^{6}$ Rulers' names and identifiers correspond to those in the Archigos data (Goemans et al., 2009), with additions from 2005-10 and revisions whenever required, e.g., leaders of São Tomé e Príncipe, for instance, who were not included in the Archigos.

In addition, the data include several indicators of general family background. Political family accounts for whether a leader is a member of a prominent political family or dynasty-for example, the Gandhis in India, where members of the leader's family have occupied the highest national political posts in the pastwhenever possible to ascertain. There is also an indicator for whether leaders were known to have been in jail any time prior to assuming office, excluding short detentions for minor misdemeanours, e.g., violations of public peace.

terms, e.g., Kérékou of Benin in 1972-91 and in 1996-2006, such a ruler is included as, e.g., "Kérékou" and as "Kérékou 2". Correspondingly, several indicator variables are adjusted, e.g., years in formal politics for Kérékou 2 (Kérékou in 1996-2006) additionally include his years as president in 1972-91. Another indicator exists that identifies the same individual as one ruler.

${ }^{6}$ Age is available for all rulers but Bonifacio Ondó Edu of Equatorial Guinea (1963-68) who is reported to have been born in 1920s by two sources, coded as 1925 (middle year for that decade) in the data.

Table 1. Descriptive statistics.

\begin{tabular}{|c|c|c|c|c|c|}
\hline Variable & Mean & Std. dev. & Min & Max & $\mathbf{N}$ \\
\hline \multicolumn{6}{|l|}{ General Indicators: } \\
\hline Age at entry into office & 53.282 & 10.649 & 17 & 85 & 1500 \\
\hline Age at exit from office & 58.694 & 11.039 & 19 & 90 & 1500 \\
\hline Tenure in office, years & 5.488 & 7.048 & 0.003 & 51.836 & 1501 \\
\hline Gender & 0.033 & 0.180 & 0 & 1 & 1501 \\
\hline Political family & 0.148 & 0.355 & 0 & 1 & 1497 \\
\hline Family background, lower & 0.219 & 0.413 & 0 & 1 & 1501 \\
\hline Family background, middle & 0.570 & 0.495 & 0 & 1 & 1501 \\
\hline Family background, upper & 0.211 & 0.408 & 0 & 1 & 1501 \\
\hline Ever been imprisoned & 0.149 & 0.356 & 0 & 1 & 1495 \\
\hline Revolutionary or opposition ${ }^{1}$ & 0.181 & 0.385 & 0 & 1 & 1495 \\
\hline \multicolumn{6}{|l|}{ Education variables: } \\
\hline Education, detail (description) & - & - & - & - & 1260 \\
\hline 3rd-level education & 0.815 & 0.389 & 0 & 1 & 1501 \\
\hline PhD degree & 0.130 & 0.336 & 0 & 1 & 1487 \\
\hline 3rd level education abroad & 0.360 & 0.480 & 0 & 1 & 1463 \\
\hline Soviet education & 0.027 & 0.162 & 0 & 1 & 1485 \\
\hline Education, categories: ${ }^{2 *}$ & & & & & 1260 \\
\hline Law & 0.278 & 0.448 & 0 & 1 & 1501 \\
\hline No 3rd-level education & 0.185 & 0.389 & 0 & 1 & 1501 \\
\hline Economics & 0.126 & 0.332 & 0 & 1 & 1501 \\
\hline Military and staff colleges & 0.117 & 0.322 & 0 & 1 & 1501 \\
\hline Humanities & 0.083 & 0.276 & 0 & 1 & 1501 \\
\hline Engineering & 0.065 & 0.247 & 0 & 1 & 1501 \\
\hline Political science & 0.043 & 0.202 & 0 & 1 & 1501 \\
\hline
\end{tabular}




\begin{tabular}{|c|c|c|c|c|c|}
\hline Variable & Mean & Std. dev. & Min & Max & $\mathbf{N}$ \\
\hline Medicine & 0.030 & 0.171 & 0 & 1 & 1501 \\
\hline Science, various & 0.019 & 0.138 & 0 & 1 & 1501 \\
\hline Degree, unknown & 0.015 & 0.123 & 0 & 1 & 1501 \\
\hline Theology & 0.013 & 0.115 & 0 & 1 & 1501 \\
\hline Agriculture or agronomy & 0.013 & 0.112 & 0 & 1 & 1501 \\
\hline Marxist philosophy, i.e., party school & 0.009 & 0.096 & 0 & 1 & 1501 \\
\hline \multicolumn{6}{|l|}{ Prior career variables: } \\
\hline Years in formal politics & 12.211 & 10.793 & 0 & 52 & 1490 \\
\hline Years, including in civil service & 15.663 & 11.782 & 0 & 52 & 1488 \\
\hline Career, detail (description) & - & - & - & - & 1500 \\
\hline Post-career, detail (description) & - & - & - & - & 1171 \\
\hline Prior career, categories:* & & & & & 1500 \\
\hline Legislative/party career & 0.467 & 0.499 & 0 & 1 & 1500 \\
\hline Career in military/security & 0.179 & 0.384 & 0 & 1 & 1500 \\
\hline Civil servant or diplomat & 0.063 & 0.244 & 0 & 1 & 1500 \\
\hline Minister, various & 0.060 & 0.238 & 0 & 1 & 1500 \\
\hline Academic career & 0.051 & 0.219 & 0 & 1 & 1500 \\
\hline Ruler's relative & 0.047 & 0.211 & 0 & 1 & 1500 \\
\hline Businessman & 0.025 & 0.157 & 0 & 1 & 1500 \\
\hline Rebel or revolutionary & 0.023 & 0.151 & 0 & 1 & 1500 \\
\hline Governor or mayor & 0.019 & 0.138 & 0 & 1 & 1500 \\
\hline Mayor of capital city & 0.019 & 0.138 & 0 & 1 & 1500 \\
\hline Judiciary & 0.017 & 0.131 & 0 & 1 & 1500 \\
\hline Trade unionist & 0.011 & 0.106 & 0 & 1 & 1500 \\
\hline \multicolumn{6}{|l|}{ Prior significant post, categories: ${ }^{3 *}$} \\
\hline PM (earlier) & 0.063 & 0.243 & 0 & 1 & 1459 \\
\hline Minister, foreign affairs & 0.037 & 0.189 & 0 & 1 & 1459 \\
\hline Minister, finance & 0.036 & 0.187 & 0 & 1 & 1459 \\
\hline Vice-president & 0.034 & 0.180 & 0 & 1 & 1459 \\
\hline House speaker & 0.030 & 0.171 & 0 & 1 & 1459 \\
\hline Minister, defence & 0.025 & 0.157 & 0 & 1 & 1459 \\
\hline Chief of general (army) staff & 0.023 & 0.151 & 0 & 1 & 1459 \\
\hline Politburo member & 0.015 & 0.122 & 0 & 1 & 1459 \\
\hline \multicolumn{6}{|l|}{ Military background variables: } \\
\hline Military rank (description) & - & - & - & - & 336 \\
\hline Military rank (NATO equivalent) & - & - & - & - & 336 \\
\hline Top NATO rank & - & - & - & - & 336 \\
\hline \multicolumn{6}{|c|}{ Variables in relation to the time in office: } \\
\hline Political outsider & 0.101 & 0.301 & 0 & 1 & 1500 \\
\hline Father of the nation & 0.067 & 0.251 & 0 & 1 & 1501 \\
\hline Collective leadership & 0.055 & 0.227 & 0 & 1 & 1501 \\
\hline Leader's political party (description) & - & - & - & - & 1339 \\
\hline Communist (extreme left) party & 0.065 & 0.246 & 0 & 1 & 1420 \\
\hline Entry type, categories: ${ }^{*}$ & & & & & 1501 \\
\hline Election & 0.398 & 0.490 & 0 & 1 & 1501 \\
\hline Selected in parliament & 0.207 & 0.405 & 0 & 1 & 1501 \\
\hline Coup & 0.123 & 0.328 & 0 & 1 & 1501 \\
\hline Interim & 0.097 & 0.296 & 0 & 1 & 1501 \\
\hline Selection, various & 0.091 & 0.288 & 0 & 1 & 1501 \\
\hline Civil war or revolt & 0.025 & 0.155 & 0 & 1 & 1501 \\
\hline Constitutional succession & 0.019 & 0.138 & 0 & 1 & 1501 \\
\hline Royal succession & 0.019 & 0.138 & 0 & 1 & 1501 \\
\hline Dedazo & 0.011 & 0.103 & 0 & 1 & 1501 \\
\hline
\end{tabular}




\begin{tabular}{|c|c|c|c|c|c|}
\hline Variable & Mean & Std. dev. & Min & Max & $\mathbf{N}$ \\
\hline Foreign installed & 0.010 & 0.099 & 0 & 1 & 1501 \\
\hline Post-career, categories (description) & -- & -- & -- & -- & 1171 \\
\hline Exit type, categories: & & & & & 1501 \\
\hline Step down/resign & 0.327 & 0.469 & 0 & 1 & 1501 \\
\hline Term limits & 0.166 & 0.372 & 0 & 1 & 1501 \\
\hline Coup & 0.138 & 0.345 & 0 & 1 & 1501 \\
\hline Lost elections & 0.133 & 0.340 & 0 & 1 & 1501 \\
\hline In office & 0.111 & 0.315 & 0 & 1 & 1501 \\
\hline Died in office & 0.062 & 0.241 & 0 & 1 & 1501 \\
\hline Civil war or revolt & 0.035 & 0.185 & 0 & 1 & 1501 \\
\hline Killed & 0.019 & 0.135 & 0 & 1 & 1501 \\
\hline Replaced by foreign powers & 0.009 & 0.093 & 0 & 1 & 1501 \\
\hline
\end{tabular}

Note: *Some leaders receive education in more than one discipline, serve in more than one significant post, or have more than one prior career. In such cases, there is an accompanying variable with additional categories included. ${ }^{1}$ Involved in a revolutionary movement or opposition in a prior non-democratic regime, or in an anti-colonial struggle. ${ }^{2}$ Most significant categories are included, i.e., psychology or pedagogy are omitted from the table. ${ }^{3}$ Several prior posts are displayed only, there exist more categories.

The data also account for the family background of leaders, whether they come from upper, middle, or working/lower-middle class families. In some cases family class origins are difficult to ascertain, however. ${ }^{7}$ For example, in the context of sub-Saharan Africa, particularly in the colonial period, the meaning of family class background is very different from what is understood by class in industrialised nations. Therefore, whenever possible, equivalent class categories were gauged in the context of social hierarchy, e.g., the family of the village chief or that of the missioners was assigned into the "middle" category. Altogether, 22 per cent of leaders have a working or lower-middle class family background, 21 per cent hail from upper-class origins, and the majority, 57 per cent, are from the middle ranks.

The second group of indicators is related to leaders' education. Education, detail (description) includes the raw data on leaders' education: detailed in 48 categories, e.g., classics; liberal arts (others); business administration; military academy, West Point; military academy, Saint-Cyr; military academy, Sandhurst; military academy, others, and so on. Altogether, 82 per cent of leaders have completed third-level (university or equivalent) education. The education of military officers is coded as third-level education only if such officers attended undergraduate degree-granting institutions, such as Saint-Cyr, the Soviet third-level military schools (following the late 1950s transition from twoyear (non-third-level) military schools into four-year higher education institutions. In turn, Education, detail

\footnotetext{
${ }^{7}$ Also, in 17 per cent of observations (253 leaders out of 1,501) bibliographic sources do not disclose family social origins or father's profession explicitly and therefore family status was imputed based on other available information about leaders' younger years. There is an auxiliary indicator to mark these observations so they can be recoded as missing instead.
}

(description) is aggregated into Education, categories with fifteen categories: 28 per cent of leaders received a law education, 13 per cent-economics or related discipline, 12 per cent-graduated from military and military staff institutions, and so on.

There is also a Ph.D. indicator whenever a leader holds a doctorate, excluding honorary doctorates, e.g., Alberto Fujimori of Peru does not hold a Ph.D. despite being a university academic prior to presidency, only an honorary Ph.D., therefore Fujimori is coded as not having a doctorate. There are also several indicators related to whether leaders received their education abroad. Three per cent of non-Soviet leaders received their university education, fully or partly, in the USSR or a Soviet satellite country during the Cold War. If leaders received more than one third-level education in different fields, their second education is also included in a second, additional Education, categories variable, e.g., Ramalho Eanes (1976-86) of Portugal received a third-level military, and later, legal, degree. Both types are accounted for.

The third group of indicators covers various aspects of rulers' prior careers. Career, detail (description) provides the raw description. Prior career, categories gives 16 categories for a primary career before office: academic, businessman, career in military/security, civil servant or diplomat, governor or mayor, international development or the EU, journalist, judiciary, lawyer, legislative/party career, mayor of capital city, ministerial appointments, priest, rebel or career revolutionary, ruler's relative, trade unionist. Because some careers are difficult to categorise in one category, Prior career 2 accounts for their second significant career, if there is any. Altogether, 47 per cent of leaders have mainly legislative or political party careers, 18 per cent have a career in military or security apparatus, and six per cent are former civil servants or diplomats.

There are also two variables for the length of politi- 
cal experience prior to assuming the highest political office. Years in formal politics account for years in official politics, such as being a member of parliament, cabinet minister, province governor or city mayor, or member of a sub-national parliament, while the second indicator additionally accounts for any political activity including party membership, working in civil service, or colonial administration. Furthermore, Prior significant post, categories variable provides additional details of political experience such as significant political posts occupied prior to assuming office, e.g., those of finance minister, defence minister, membership of the politburo, or head of royal military household, etc. Altogether, there are three separate significant post variables, with some leaders assigned only one significant prior post if they only had one. From these data it is possible to ascertain not only the ruler's prior career path but also the degree of affinity with previous rulers, e.g., whether the current leader is a close relative of the previous one, or a designated successor.

The fourth group includes details regarding whether a leader is a career military officer or a former military officer, excluding leaders who underwent mandatory military training or military draft in the past. The data also include indicators for the highest military rank obtained by rulers prior to assuming office, as well as their highest rank in the national military at the time. ${ }^{8}$ Another group of indicators relates to what happens to leaders after leaving office. Post-career, categories assigns former leaders' pursuits into several categories, such as ambassador, arrested and/or imprisoned, business, civil servant, died/incapacitated in office, exile, cabinet minister, non-profit or academic, and so on. The post-tenure categories may also be desegregated and aggregated into a smaller or larger number of categories. In turn, the final group of variables includes various details pertaining to leaders' time in office, or the type of entry and exit from office, e.g., constitutional succession, term limits, or a coup. Also, 7 per cent of leaders are Fathers of the nation, 6 per cent rule under collective leadership, 7 per cent are from the Communist, Marxist or any other extreme-left party family, among other things.

\section{Leaders and their Careers in Democracy and Dictatorship}

The democratic form of government is lauded for various positive policy outcomes, e.g., higher education spending (Stasavage, 2005), better healthcare (Kudamatsu, 2012), more effective control of corruption, albeit only after a long history of democracy

\footnotetext{
8 Where a ruler is a retired officer at the time of assuming office, the rank at the time of retirement is used, whenever such data are available. Ranks bestowed on leaders while in office are not counted, only those received prior.
}

(Treisman, 2000), and steadier economic growth rates (Przeworski, Alvarez, Cheibub, \& Limongi, 2000), among other things. Democracy also attracts better educated, and therefore generally better-because the superior education of leaders arguably signals their honesty and competence-political leaders (Besley \& Reynal-Querol, 2011). The difference between leaders in democracy and dictatorship does not have to be confined to educational attainment, however. Rulers may vary in terms of the type of education, family background, typical career paths and length thereof, and the significant political posts they are expected to attain on their way to the highest office, among other things. In turn, a better understanding of leaders' distinct careers and traits may improve our knowledge of elite politics and recruitment across different political regimes.

In this section I demonstrate how the Cursus Honorum data can be employed to investigate whether democracy and dictatorship are associated with "different" leaders. Because the primary aim of this paper is to introduce and discuss the data, I forsake a more detailed discussion as to why political regimes may elevate and "select" as their leaders those individuals who share particular background traits. Instead, I rely on previous scholarship that examined the selection of leaders in comparative context (e.g., Besley \& ReynalQuerol, 2011; Bienen \& van de Walle, 1991; Dreher et al., 2009; Eulau \& Czudnowski, 1972; Pérez-Liñán, 2009). Based on this literature, the expectation is that democracies are more likely to feature leaders with a better education (e.g., Besley \& Reynal-Querol, 2011), legal background, education in law and economics (e.g., Eulau \& Czudnowski, 1972), and to have longer political careers and experience (e.g., Linz, 1994). In contrast, leaders in non-democracies are more likely to have lower education (e.g., Besley \& Reynal-Querol, 2011), military background (e.g., Bienen \& van de Walle, 1991; Svolik, 2012), shorter political careers, and less experience (e.g., Bienen \& van de Walle, 1991; Ludwig, 2002).

For the sake of comparison, leaders in democracies are those who enter office in a year when their country has a Polity 2 score of +6 and above, and leaders in dictatorships are those who enter when the Polity2 score is lower than +6 . Several countries not covered by Marshall and Jaggers (2011) are coded as democracies if they are categorised as "Free" by the Freedom House however, for example, Barbados, Bahamas and Iceland.

Differences in personal background are presented in several graphs. The background categories are sorted by the magnitude of differences between leaders in two political regimes. In other words, democratic and nondemocratic leaders are most different in terms of categories at the top of each figure, and they are the most similar at the bottom. Figure 1 displays differences in general and family background, in per cent. 
The results indicate that democracies and dictatorships have a similar percentage of leaders who are political outsiders, were imprisoned in the past, or hail from prominent political families, as these categories are at the bottom of Figure 1. Non-democratic leaders are four years younger than their democratic counterparts, at 51 years when they enter office. The biggest difference, however, is in terms of middle-class family background: 63 per cent of leaders in democracies are middle-class as opposed to 51 per cent in non-democracies. Also, 25 per cent of rulers in dictatorships spring from a lower class background versus 19 per cent in democracies.

Figure 2 displays differences in leaders' education. Earlier studies found the predominance of former lawyers in democracies (Eulau \& Czudnowski, 1972). As expected therefore, there are more lawyers among democrats, and more leaders with education in military and staff colleges exist among dictators. Likewise, 28 per cent of rulers in non-democracies-versus only 10 per cent in democracies-have no college education. In democracies, 18 per cent hold degrees in economics, 17 per cent have Ph.D. degrees and 10 per cent hold undergraduate degrees in humanities-versus only 7, 8 and 6 per cent respectively in dictatorships. However, democratic leaders are, broadly speaking, not that different in terms of whether they received their educa- tion abroad in general (33 v. 39 per cent), or in the countries of the Soviet block in particular. There are only 40 rulers with Soviet education altogether, e.g., Bachelet of Chile who studied medicine in the GDR, or Dos Santos of Angola with a Soviet engineering degree. ${ }^{9}$

In general, democratic leaders do seem to have a better education overall, in line with previous findings in Besley and Reynal-Querol (2011) who also stipulated that the improved education of leaders was related to their competence and public-spiritedness. This argument is debatable, however, as in former or current authoritarian regimes where formal education lacks in civic classes and democratic learning, better education may equally indoctrinate (Klingemann, 1966). Also, Carnes and Lupu $(2015$, p. 47) find that universityeducated leaders do not perform any better-i.e., do not govern during periods of higher economic growth, do not pass more legislative bills, are no less corrupt.

\footnotetext{
${ }^{9}$ Leaders in the (former) USSR or Soviet satellite countries who received their education in their home countries during the Cold war are not included in the Soviet education category, i.e., Soviet education must be received abroad. An East European leader with an education in the USSR is regarded to have received a Soviet education as opposed to a leader who received it in his own East European country during the Cold war.
}

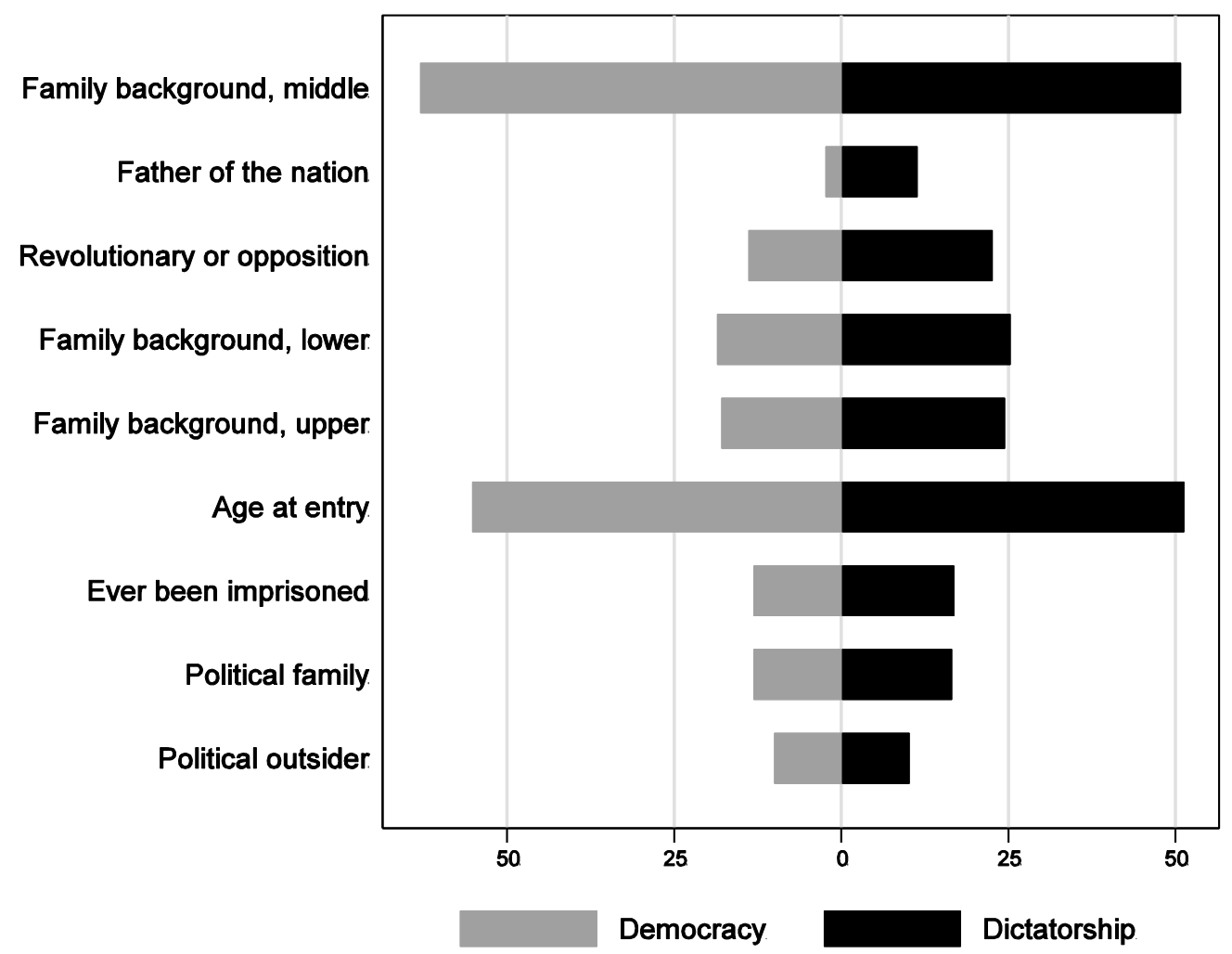

Figure 1. General background of political leaders. Note: Categories report percentage of leaders in democracy and dictatorship with particular traits. However, Age at entry includes the average values instead of percentage. Categories are sorted by differences between leaders who enter office in more and less democratic regimes as explained in text. 


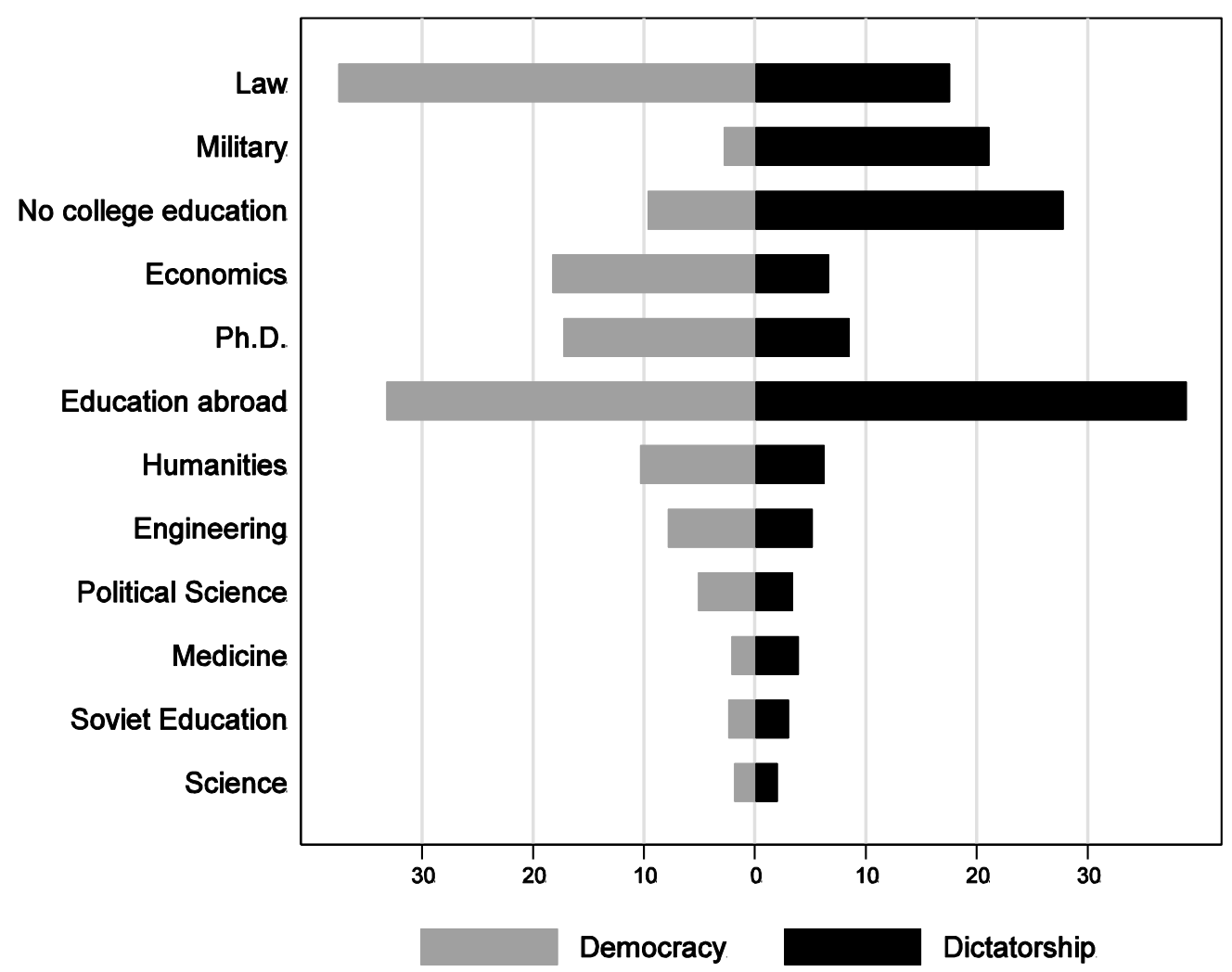

Figure 2. Education of political leaders. Note: Categories report percentage of leaders in democracy and dictatorship with particular educational background. Selected categories are displayed only (e.g., theology, agronomy and other infrequent categories are omitted). All categories are the field of study except Education abroad, Soviet education, and Ph.D. which can be in any field. Categories are sorted by differences between leaders who enter office in more and less democratic regimes.

We can also compare leaders' prior careers and the posts they tend to occupy prior to tenure in the highest office. In Figure 3, 65 per cent of leaders (the bar is truncated in the interest of visibility) in democracies and 28 per cent in non-democracies have predominantly legislative or party careers. However, 34 per cent in dictatorships-versus only 3 per cent in democracies-come from military or security career paths. Even excluding leaders in military regimes, 21 per cent of rulers in monarchies, party and personal regimes have a military career background. Indeed, many nondemocratic leaders wear the uniform to exert political control over their militaries (Svolik, 2012, p. 11).

The Cursus Honorum data also allow us to compare leaders in terms of the length of their political careers, whether in formal politics or in politics in general. The second category, years in politics prior to assuming the highest political office, additionally includes years in civil service and any politics-related activity from the time of joining the party or movement, for instance. As can be seen from Figure 3, democratic leaders enjoy lengthier political careers, whether in formal politics or in general: on average they clock 16 and 19 years versus those in non-democracies who manage 9 and 12 years, respectively. However, many leaders in dictatorships are perhaps more connected: 8 per cent are relatives of the previous ruler, albeit many of them-but not all-are found in monarchies, as expected.

From the data, we can also compare various ways under which leaders may assume, or lose, their office. Figure 4 shows that the majority of leaders in democracies assume office via regular means, either as a result of election-57 per cent-or selection in parliament -35 per cent. By contrast, only 22 and 6 per cent of leaders in dictatorships assume office as a result of elections or within the legislature. Instead, 25 per cent come to power through a coup and 18 per cent are selected, i.e., chosen by members of the military junta, at politburo meetings, etc. ${ }^{10}$ Leaders can also assume office as the result of royal succession in monarchies; as a

\footnotetext{
10 In cases where it is difficult to assign a single category to the type of entry, two categories may be assigned, e.g., a ruler can enter through the process of a constitutional succession and a coup at the same time. Consider Arosemena Monroy (196163) of Ecuador who participated in the rebellion against his president (Lentz, 1994, p. 238). After a coup, Monroy, as vice president, assumed presidential office (hence the entry is categorised as constitutional succession and coup).
} 


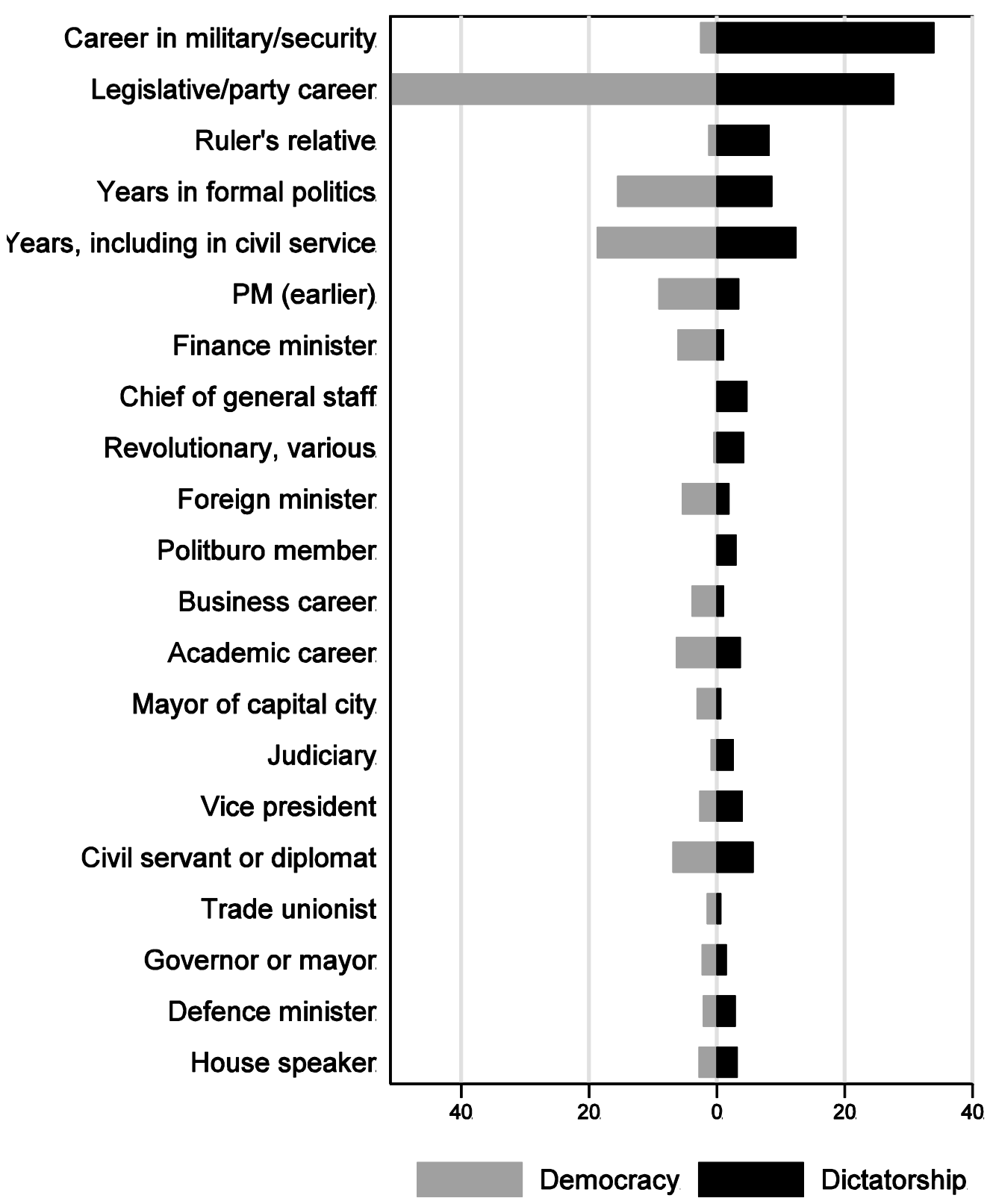

Figure 3. Prior career and posts of political leaders. Note: Categories report percentage of leaders in democracy and dictatorship with particular career and professional traits, except for Years in formal politics and Years, including in civil service that report the average values instead. Categories are not mutually exclusive. Categories are sorted by differences between leaders who enter in more and less democratic regimes.

result of the explicit choice of the preceding ruler, dedazo, e.g., Mexico prior to 2000 (this category can be collapsed together with selection); they can be installed by, or enter office with the significant assistance of, a foreign power (e.g., Babrak Karmal in 1979, Mohammad Najibullah in 1986 and Hamid Karzai in 2001-all in Afghanistan). Every tenth leader in the data is designated as interim. Such leaders enter office typically following the death, incapacity or resignation of the preceding leader and remain in that office for a short duration, usually less than a year, and resign afterwards. ${ }^{11}$

${ }^{11}$ For example, the Senate speaker of Gabon, Rogombé, assumed the office of interim head of state for four months after President Bongo died in 2009 only to return to her previous post in the Senate when the new ruler was sworn in. Likewise, some military leaders are also considered interim whenever they, shortly after assuming power, declare that democratic elections are to be held and then exclude themselves from such elections (e.g., General Abraham of Haiti in 1990). In monarchies, a regent who serves shorter than one year is also regarded as interim. 

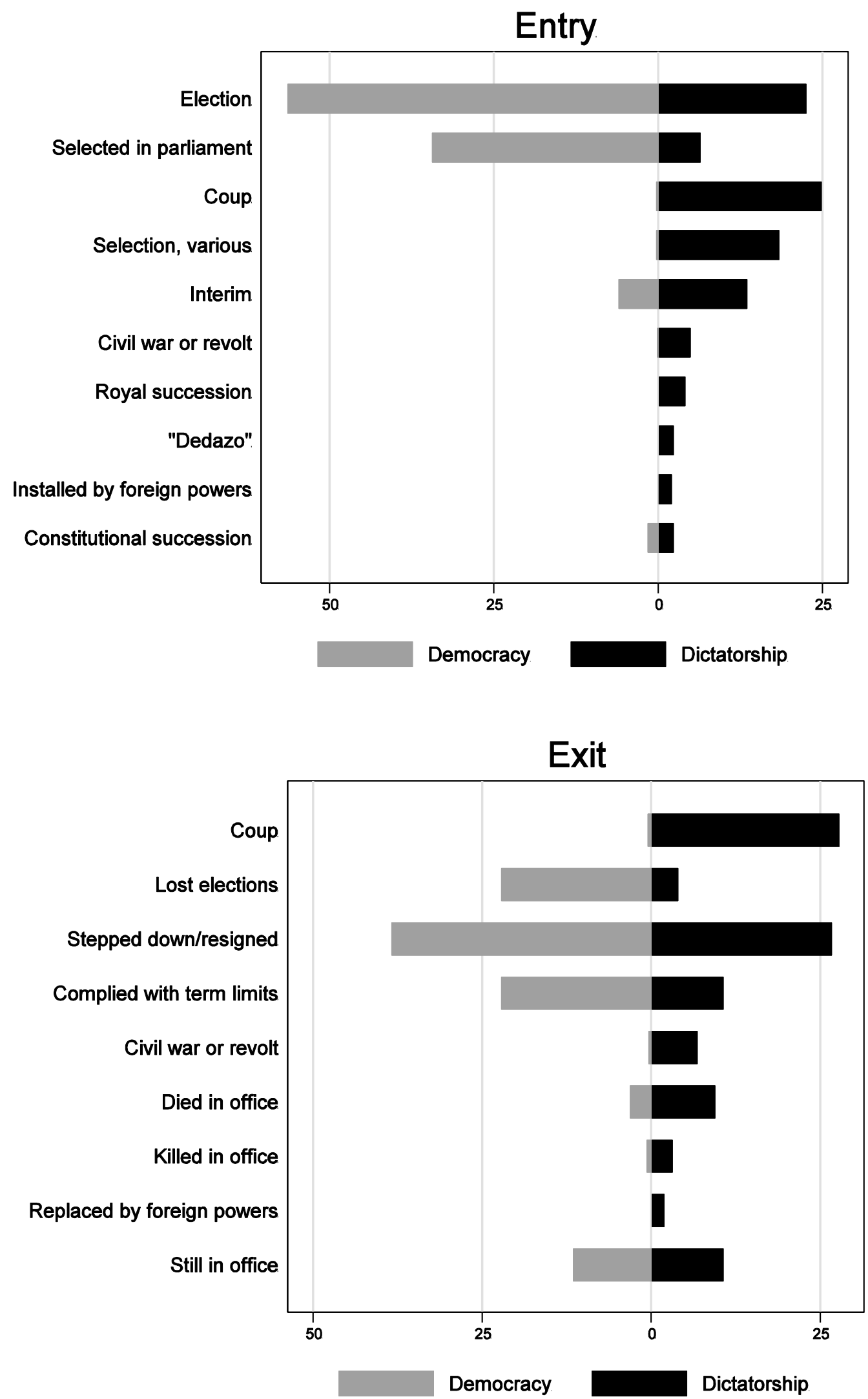

Figure 4. Entry and exit in democracy and dictatorship. Note: Categories report percentage of leaders who enter or exit office in democracy and dictatorship under each category. Categories are mutually exclusive and are sorted by differences between leaders who enter in more and less democratic regimes. 
The majority of democratic leaders also leave office in a regular manner: 39 per cent resign even though they could have remained in politics, 22 per cent comply with term limits, and 22 per cent lose election and leave. In contrast, politics in dictatorships is more violent: 28 per cent lose office in a coup, 7 per cent as a result of revolt or civil war and 3 per cent are killed (Iqbal \& Zorn, 2008). Nine per cent die in office. ${ }^{12}$ Still, many nondemocratic leaders leave office in a regular manner: 10 per cent comply with term limits (Baturo, 2014), 25 per cent resign peacefully, and 3 per cent lose elections. Also, excluding leaders who die in office or are forced into exile or are imprisoned, overall half of former rulers remain in politics while on average 8 per cent turn to business, 10 per cent primarily engage in non-governmental and charitable activities or turn to academic work, and 7 per cent are civil servants, e.g., ambassadors.

Until now, I have relied on descriptive statistics to explore the main differences between leaders in democracies and dictatorships. Political regimes are more likely to "select" as their leaders those individuals who share particular background traits, e.g., former or current military officers in dictatorships or former solicitors in democracies. However, apart from political regimes other factors may equally influence the selection of leaders. For example, different ruling coalitions may face different security environments when choosing their leaders so that at the time of war or insurgency military officers are elevated. ${ }^{13}$ Similarly, economic crises, regime institutionalisation, country governability may equally matter in leader selection.

As a simple test to account for possible omitted factors, I specify several models to predict whether leaders with specific traits enter office. The independent variables are Polity2 and Regime durability to account for democracy and regime strength (Marshall \& Jaggers, 2011), Cold war dummy, War-for an armed conflict with at least 25 battle-related deaths (Gleditsch, Wallensteen, Eriksson, Sollenberg, \& Strand, 2002), GDP per capita (log)-all with the values for the first year in office, and the Economic growth in a year prior to assuming office (Heston, Summers, \& Aten, 2012). Since the data set includes more than 50 indicators, I choose six dependent variables that appear to differentiate democrats and dictators, as seen from Figures 1 to 3: Family background, middle, Revolutionary background, Law degree, Economics, Military career, Years in politics (in general). Probit models are fitted to predict all but Years in politics where the Poisson regression is used; models use robust standard errors clus-

\footnotetext{
12 In the majority of cases this category is a death in office, with few exceptions being whenever a leader was so severely incapacitated that he could not continue in office, e.g., Ariel Sharon of Israel in 2006.

13 I thank an anonymous referee for this point.
}

tered by country.

Table 2, columns 1-6 display the results. In brief, leaders with a revolutionary background are more likely to emerge in less durable-or new-regimes, more democratic regimes are more likely to select more experienced leaders, leaders with law and economics degrees, while non-democratic ones promote those with military careers. There are also more leaders with backgrounds in economics after the end of the Cold war. There is no systematic evidence that military conflict or economic crises tend to elevate leaders with specific traits, however. Also, Family status is too idiosyncratic to be explained by the chosen predictors.

In general, democratic leaders do appear to be more experienced: they serve longer in various political posts, are more likely to occupy significant posts in the past. Do leaders across different nondemocratic regimes also differ in terms of their background, experience, and traits? The section that follows briefly compares leaders across dictatorships.

\section{Leaders and their Careers in Dictatorships}

In a path-setting study of non-democratic regimes, Geddes (1999) argued that significant differences among dictatorships can be explained by the strength of autonomous political institutions and by different incentive structures in personal, party, and military dictatorships. Scholars find that single-party regimes are generally most durable (Gandhi, 2008). One of the reasons behind their resilience is that political elites in such regimes are all co-opted under one umbrella organisation-single party, and all have a vested interest in regime continuity. Lower-ranked officials first perform a lengthy and costly service for the party while climbing the career ladder, later capitalising on their prior career when they reach the higher levels of party hierarchy (Svolik, 2012, pp. 168-169). Similarly, in democratic polities it is very unusual to climb to the summit of power without progressing through a number of steps in the political career (Eulau \& Czudnowski, 1972). Likewise, in more institutionalised non-democratic regimes, e.g., USSR or contemporary China, the careers of future leaders span decades in the lower offices. We should expect, therefore, that political leaders in party regimes will have more political experience than those in personal regimes, and certainly more than those in military administrations.

Even though leaders in nondemocratic regimes primarily choose policies that prolong their survival in office (Bueno de Mesquita et al., 2003; Tullock, 1987), dictators' motives may be more complicated. Some leaders may also aim to maximise their personal consumption (Wintrobe, 1998, p. 79). It is conceivable that the observed heterogeneity among dictators, with some being more benevolent and others-kleptocratic, may in part be driven by their diverse backgrounds. For 
4 COGITATIO

Table 2. Leaders and their background in democracy and dictatorship.

\begin{tabular}{|c|c|c|c|c|c|c|c|c|c|c|c|c|}
\hline & \multicolumn{6}{|c|}{ All Countries: } & \multicolumn{6}{|c|}{ Dictatorships: } \\
\hline & (1) & (2) & (3) & (4) & (5) & (6) & (7) & (8) & (9) & (10) & (11) & (12) \\
\hline & $\begin{array}{l}\text { Family, } \\
\text { middle }\end{array}$ & $\begin{array}{l}\text { Rev. or } \\
\text { opposition }\end{array}$ & Law & Economics & $\begin{array}{l}\text { Military } \\
\text { career }\end{array}$ & $\begin{array}{l}\text { Years in } \\
\text { politics }\end{array}$ & $\begin{array}{l}\text { Family, } \\
\text { middle }\end{array}$ & $\begin{array}{l}\text { Rev. or } \\
\text { opposition }\end{array}$ & Law & $\begin{array}{l}\text { Military } \\
\text { career }\end{array}$ & No 2 & $\begin{array}{l}\text { Years in } \\
\text { politics }\end{array}$ \\
\hline Polity2 & $\begin{array}{l}0.010 \\
(0.008)\end{array}$ & $\begin{array}{l}0.020 \\
(0.015)\end{array}$ & $\begin{array}{l}0.055^{* * *} \\
(0.010)\end{array}$ & $\begin{array}{l}0.042 * * * \\
(0.010)\end{array}$ & $\begin{array}{l}-0.107^{* * *} \\
(0.010)\end{array}$ & $\begin{array}{l}0.037^{* * *} \\
(0.007)\end{array}$ & & & & & & \\
\hline Cold war & $\begin{array}{l}0.025 \\
(0.081)\end{array}$ & $\begin{array}{l}-0.057 \\
(0.136)\end{array}$ & $\begin{array}{l}0.409 * * * \\
(0.088)\end{array}$ & $\begin{array}{l}-0.459 * * * \\
(0.102)\end{array}$ & $\begin{array}{l}0.348^{* *} \\
(0.128)\end{array}$ & $\begin{array}{l}0.128^{* *} \\
(0.049)\end{array}$ & $\begin{array}{l}0.077 \\
(0.175)\end{array}$ & $\begin{array}{l}-0.366^{* *} \\
(0.169)\end{array}$ & $\begin{array}{l}0.163 \\
(0.246)\end{array}$ & $\begin{array}{l}0.579 * * \\
(0.195)\end{array}$ & $\begin{array}{l}-0.205 \\
(0.205)\end{array}$ & $\begin{array}{l}-0.153 \\
(0.128)\end{array}$ \\
\hline War & $\begin{array}{l}-0.048 \\
(0.116)\end{array}$ & $\begin{array}{l}0.408+ \\
(0.218)\end{array}$ & $\begin{array}{l}-0.139 \\
(0.142)\end{array}$ & $\begin{array}{l}0.055 \\
(0.171)\end{array}$ & $\begin{array}{l}0.064 \\
(0.175)\end{array}$ & $\begin{array}{l}0.000 \\
(0.077)\end{array}$ & $\begin{array}{l}0.064 \\
(0.182)\end{array}$ & $\begin{array}{l}0.757^{* * *} \\
(0.198)\end{array}$ & $\begin{array}{l}-0.053 \\
(0.168)\end{array}$ & $\begin{array}{l}-0.251 \\
(0.165)\end{array}$ & $\begin{array}{l}-0.347 \\
(0.218)\end{array}$ & $\begin{array}{l}-0.071 \\
(0.113)\end{array}$ \\
\hline Income pc (log) & $\begin{array}{l}0.000 \\
(0.000)\end{array}$ & $\begin{array}{l}-0.000 \\
(0.000)\end{array}$ & $\begin{array}{l}0.000 \\
(0.000)\end{array}$ & $\begin{array}{l}0.000 \\
(0.000)\end{array}$ & $\begin{array}{l}-0.000+ \\
(0.000)\end{array}$ & $\begin{array}{l}0.000 \\
(0.000)\end{array}$ & $\begin{array}{l}-0.000 \\
(0.000)\end{array}$ & $\begin{array}{l}-0.000+ \\
(0.000)\end{array}$ & $\begin{array}{l}0.000 \\
(0.000)\end{array}$ & $\begin{array}{l}-0.000^{* *} \\
(0.000)\end{array}$ & $\begin{array}{l}-0.000 \\
(0.000)\end{array}$ & $\begin{array}{l}0.000^{* *} \\
(0.000)\end{array}$ \\
\hline Econ. growth, $t-1$ & $\begin{array}{l}-0.003 \\
(0.006)\end{array}$ & $\begin{array}{l}0.003 \\
(0.009)\end{array}$ & $\begin{array}{l}-0.005 \\
(0.009)\end{array}$ & $\begin{array}{l}0.002 \\
(0.007)\end{array}$ & $\begin{array}{l}0.004 \\
(0.008)\end{array}$ & $\begin{array}{l}0.009+ \\
(0.005)\end{array}$ & $\begin{array}{l}-0.008 \\
(0.011)\end{array}$ & $\begin{array}{l}0.010 \\
(0.014)\end{array}$ & $\begin{array}{l}0.001 \\
(0.011)\end{array}$ & $\begin{array}{l}0.000 \\
(0.011)\end{array}$ & $\begin{array}{l}0.026^{* *} \\
(0.013)\end{array}$ & $\begin{array}{l}0.010 \\
(0.008)\end{array}$ \\
\hline Regime durability & $\begin{array}{l}-0.002 \\
(0.002)\end{array}$ & $\begin{array}{l}-0.010^{* *} \\
(0.004)\end{array}$ & $\begin{array}{l}0.001 \\
(0.002)\end{array}$ & $\begin{array}{l}-0.001 \\
(0.002)\end{array}$ & $\begin{array}{l}-0.010+ \\
(0.006)\end{array}$ & $\begin{array}{l}0.001 \\
(0.001)\end{array}$ & $\begin{array}{l}0.002 \\
(0.006)\end{array}$ & $\begin{array}{l}-0.010 \\
(0.007)\end{array}$ & $\begin{array}{l}0.008 \\
(0.007)\end{array}$ & $\begin{array}{l}-0.006 \\
(0.007)\end{array}$ & $\begin{array}{l}0.009 \\
(0.007)\end{array}$ & $\begin{array}{l}0.009 * * * \\
(0.002)\end{array}$ \\
\hline Military regime & & & & & & & $\begin{array}{l}0.587^{* *} \\
(0.208)\end{array}$ & $\begin{array}{l}-0.810^{* *} \\
(0.278)\end{array}$ & $\begin{array}{l}-0.284 \\
(0.244)\end{array}$ & $\begin{array}{l}0.768^{* * *} \\
(0.222)\end{array}$ & $\begin{array}{l}-0.497 * * \\
(0.246)\end{array}$ & $\begin{array}{l}-0.426^{* *} \\
(0.206)\end{array}$ \\
\hline Monarchy & & & & & & & $\begin{array}{l}-1.227^{* *} \\
(0.586)\end{array}$ & - & $\begin{array}{l}-0.602 \\
(0.647)\end{array}$ & $\begin{array}{l}-1.465^{* *} \\
(0.648)\end{array}$ & - & $\begin{array}{l}-0.824+ \\
(0.468)\end{array}$ \\
\hline Single party & & & & & & & $\begin{array}{l}0.190 \\
(0.251)\end{array}$ & $\begin{array}{l}0.588^{* *} \\
(0.269)\end{array}$ & $\begin{array}{l}0.062 \\
(0.234)\end{array}$ & $\begin{array}{l}-0.421 \\
(0.258)\end{array}$ & $\begin{array}{l}0.234 \\
(0.226)\end{array}$ & $\begin{array}{l}0.349 * * \\
(0.170)\end{array}$ \\
\hline Constant & $\begin{array}{l}0.230^{* *} \\
(0.098) \\
\end{array}$ & $\begin{array}{l}-0.910 * * * \\
(0.170)\end{array}$ & $\begin{array}{l}-1.049 * * * \\
(0.104)\end{array}$ & $\begin{array}{l}-1.172^{* * *} \\
(0.119)\end{array}$ & $\begin{array}{l}-0.619 * * * \\
(0.149)\end{array}$ & $\begin{array}{l}2.365^{* * *} \\
(0.073) \\
\end{array}$ & $\begin{array}{l}-0.147 \\
(0.222) \\
\end{array}$ & $\begin{array}{l}-0.650^{* *} \\
(0.249) \\
\end{array}$ & $\begin{array}{l}-1.085^{* * *} \\
(0.242)\end{array}$ & $\begin{array}{l}-0.022 \\
(0.216) \\
\end{array}$ & $\begin{array}{l}-0.744^{* *} \\
(0.244) \\
\end{array}$ & $\begin{array}{l}2.212^{* * *} \\
(0.160) \\
\end{array}$ \\
\hline$N$ & 1187 & 1182 & 1187 & 1187 & 1186 & 1177 & 346 & 333 & 346 & 345 & 333 & 345 \\
\hline$N$ of countries & 145 & 145 & 145 & 145 & 145 & 145 & 95 & 88 & 95 & 95 & 88 & 95 \\
\hline$\chi^{2}$ & 2.638 & 33.404 & 60.387 & 78.628 & 172.491 & 103.283 & 24.717 & 68.203 & 5.030 & 61.894 & 28.282 & 75.819 \\
\hline
\end{tabular}

Notes: Columns 1-5 and 7-11 report the results of probit regression models with the dependent variables indicated in the top row; columns 6 and 12 are Poisson regression models with the count of years in politics, including in civil service, as the dependent variable. All variables are for the year of entry in office, Economic growth is for the year preceding entry into office. Monarchy predicts failure perfectly and is therefore omitted in Models 8 and 11 . Cluster-robust standard errors in parentheses + $\mathrm{p}<0.10, * * \mathrm{p}<0.05, * * * \mathrm{p}<0.001$. 
instance, Brazilian military leaders from 1964-85 who arguably opted for economic development over personal enrichment were different from rulers in other military regimes in that they all came from secure wealthy and middle-class backgrounds, many receiving an excellent education in the War College (Skidmore, 1988). Admittedly, it is equally possible that the personal background of dictators is unrelated to their behaviour in office. With the assistance of the new data, this question can be addressed empirically. As a first test, in this section I only compare whether different types of dictatorships are associated with different types of dictators. Leaders of military, monarchies, single-party, personal nondemocratic regimes are assigned into four different types using the data from Geddes, Wright and Frantz (2012). Regimes are categorised for the first year in office of each ruler.

Because almost all leaders of military regimes have undertaken a military education, Figure 5 only compares education background of leaders in personal and party dictatorships instead. The differences in educational backgrounds among party rulers and personal rulers are not significant: every third leader has no university education in both regime types, 15 and 18 per cent in personal and party regimes have a law background, while the differences in terms of other categories are small. The only difference that stands out is that 18 per cent of leaders in personal regimes have undergone military education as opposed to 10 per cent only of those in party regimes. In turn, Figure 6 charts differences in career paths in more and less institutionalised dictatorships, i.e., in party and personal rulerships. As expected, the main difference is that personal rulers are more likely to have careers in military and security, while the experience of party leaders lies within the party or legislature.

Comparative scholarship has found that personalist regimes are markedly different from other nondemocratic regimes (e.g., Escribà-Folch \& Wright, 2015; Frantz \& Kendall-Taylor, 2014; Weeks, 2012; Wright, 2008). The descriptive statistics displayed in Figures 5 and 6 suggest that differences in the educational and professional profiles of party rulers and personal dictators are not dramatic. It is therefore very likely that personal dictatorships stand out because of the relative lack of constraints on their rulers-relative to other regime types-not because of differences in rulers' traits.

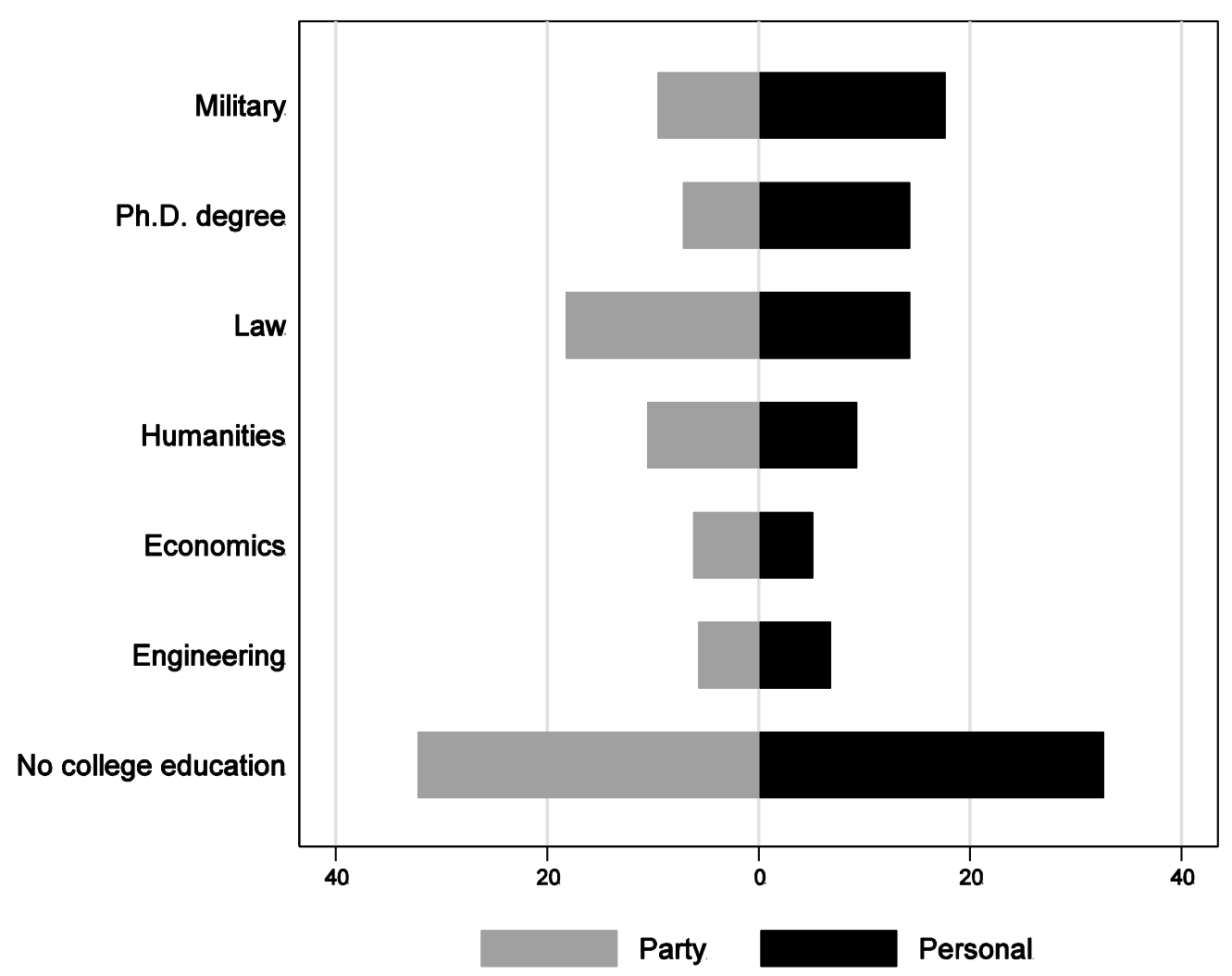

Figure 5. Are personalist dictators different from party rulers? Educational background. Note: Categories report percentage of leaders under each category in different regimes, only the most numerous categories are included. 


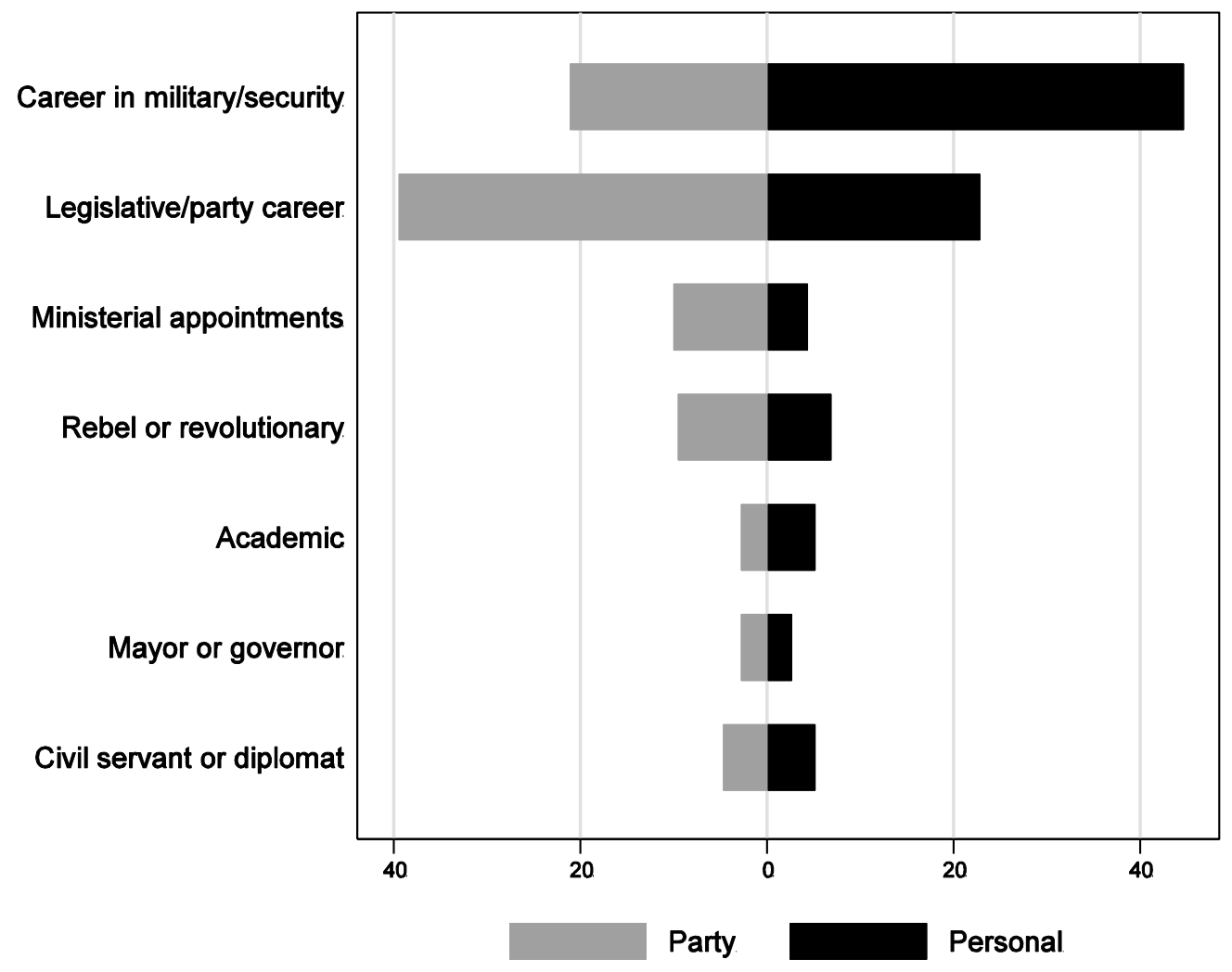

Figure 6. Are personalist dictators different from party rulers? Career background. Note: Categories report percentage of leaders under each category in different regimes, only the most numerous categories are included.

What is noticeable, however, is that dictators in different regime types may be "recruited" from different family class backgrounds. Figure 7 compares the family backgrounds of rulers in military, party, and personal dictatorships. Monarchies are omitted since their rulers come from upper family background by definition. The differences are quite stark: 67 per cent of leaders in military regimes hail from a middle-class family background, as opposed to 46 and 42 per cent only in party and personal dictatorships respectively. There are also only 17 per cent of military rulers with lower class backgrounds, as opposed to 38 and 41 per cent in other regime types. These differences are also statistically significant based on the chi-square test of association. Does this finding go beyond the question of selection effect of different regimes, i.e., does family background also matter for policy outcomes? We know that the socioeconomic family background of democratic leaders affect their economic policy preferences (Hayo \& Neumeier, 2014). In a study that examines presidents, Baturo (2014) shows that calculations to remain in office depend on, inter alia, personal concerns over future immunity and status. Further studies may also examine if military leaders with more secure family backgrounds are associated with different policies or whether such leaders are more inclined to retire to a life of comparable status as opposed to clinging onto office.
We can also compare leaders' experience. Figure 8 charts political experience in different dictatorships. It turns out that rulers of party regimes must indeed climb the "greasy pole" the longest: their average time in formal politics is 12 years (17 years in politics in total), as opposed to six years (9 years total) in personal regimes, and only four years (6 altogether) in military juntas. The median length of experience is 2-3 years shorter than the average length across all four regime types. In the section that follows, I discuss whether political experience matters and suggest possible venues for future research.

Earlier I compared democratic and less democratic leaders using regression models. Similarly, we can compare across non-democratic regimes only. The sole difference is that instead of Polity 2, models 7-12 in Table 2 include three regime types as independent variables with Personalist regime as the baseline omitted category. Also, instead of Economics degree that is uncommon in dictatorships, I predict whether particular dictatorships are more likely to be governed by former "No 2s", i.e., prime-ministers, vice-presidents, other officials ranked second formally (e.g., party's second secretary in party regimes).

The results displayed in Table 2 indicate that leaders of military regimes are more likely to share the middle-class family background, (not surprisingly) have 
prior military career, be less experienced and not come from "No 2" positions. In turn, leaders of party regimes are more likely to participate in revolutionary movements and have more years of experience in politics. In general, more durable regimes with more developed economies are also more likely to have more experienced leaders, while "No $2 s$ " are more likely to assume office at a time of economic growth. Overall, I interpret the results to indicate that more institutionalised dictatorships "select" more experienced leaders.

The Cursus Honorum data also include indicators for the highest military ranks attained prior to assuming office. Additionally, the ranks are "normalised" as NATO military ranks, i.e., the equivalent of the highest obtained rank, according to the NATO classification, from OR-4 to OF-10, where OF-1 to OF-5 are the ranks from lieutenant to colonel; OF-6 is brigadier general (generally, any 1-star general, including major-generals and rear-admirals); OF-7 is any 2-star general or admiral, can be also called division general, or lieutenant (2star) general, or brigadier-general (Argentina) or major (2-star) general in some militaries; OF-8 is division (3star) general, or lieutenant (3-star) general, or colonelgeneral (3-star); ${ }^{14}$ OF-9 is any 4 -star general, usually army general or in some cases lieutenant-general; ${ }^{15}$ OF-10 is a field marshall or a 5-star general. Finally, while there is no NATO classification on the further ranks, two generalissimo in the dataset, Franco of Spain and Chiang Kai-shek of Taiwan, are entered as OF-11.

${ }^{14}$ As OF-6, brigadier general (1-star general) is generally equivalent to major-general (1-star general). Lieutenant-general (3star general) in most militaries is categorised as OF-8, however, OF-8 is equivalent to colonel-general in the USSR and its satellites prior to 1989 (where lieutenant-general is a 2-star general instead). Since 1943, colonel-generals in USSR have worn three stars, so Pettibone $(2009$, p. 905$)$ compares this rank to the US lieutenant general.

${ }^{15}$ Similar adjustments are made for other nations, for instance, lieutenant-general is the highest obtainable rank in the Argentine military, therefore it is categorised as OF-9.

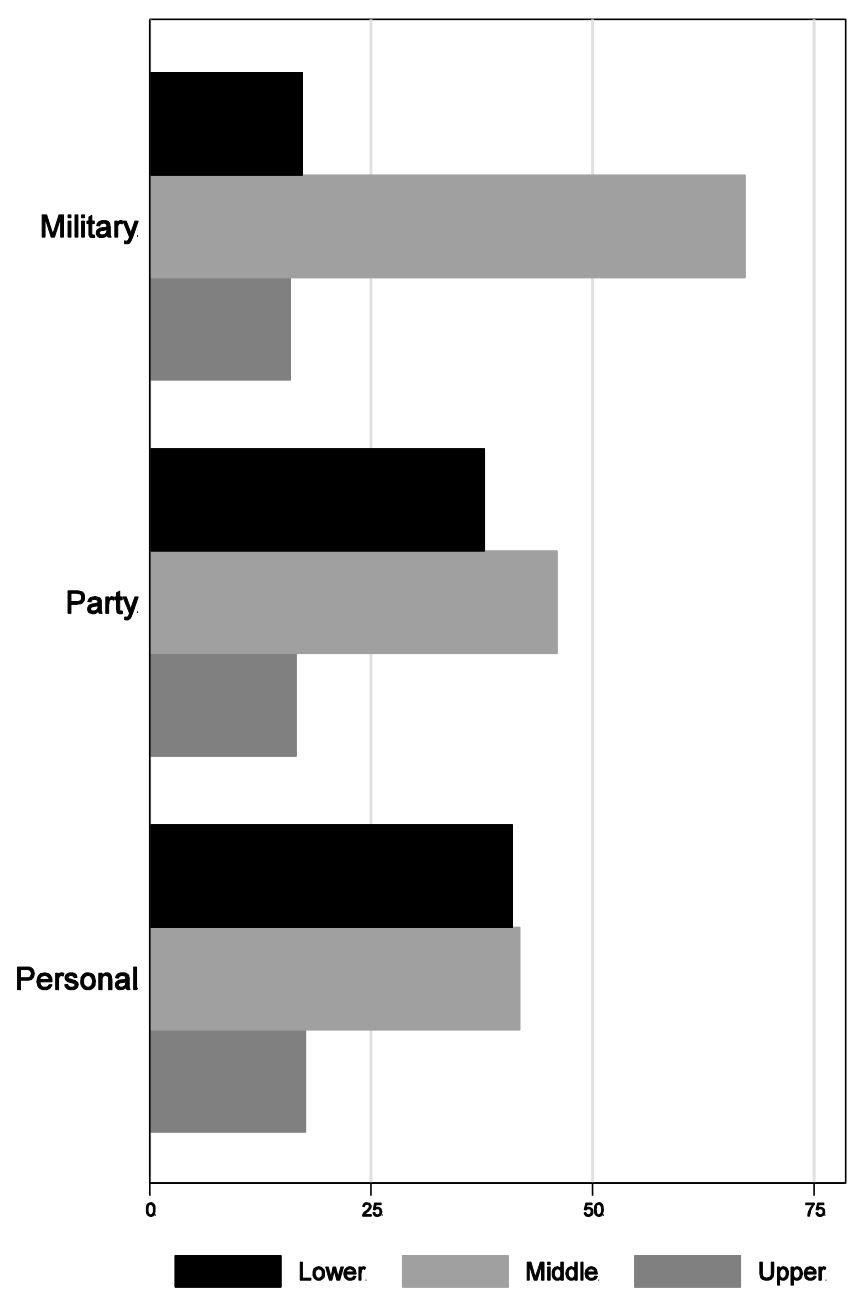

Figure 7. Family background of dictators. Note: Categories report percentage of leaders under each category of family class background. Monarchy is omitted as almost all monarchs are in the upper class category. 


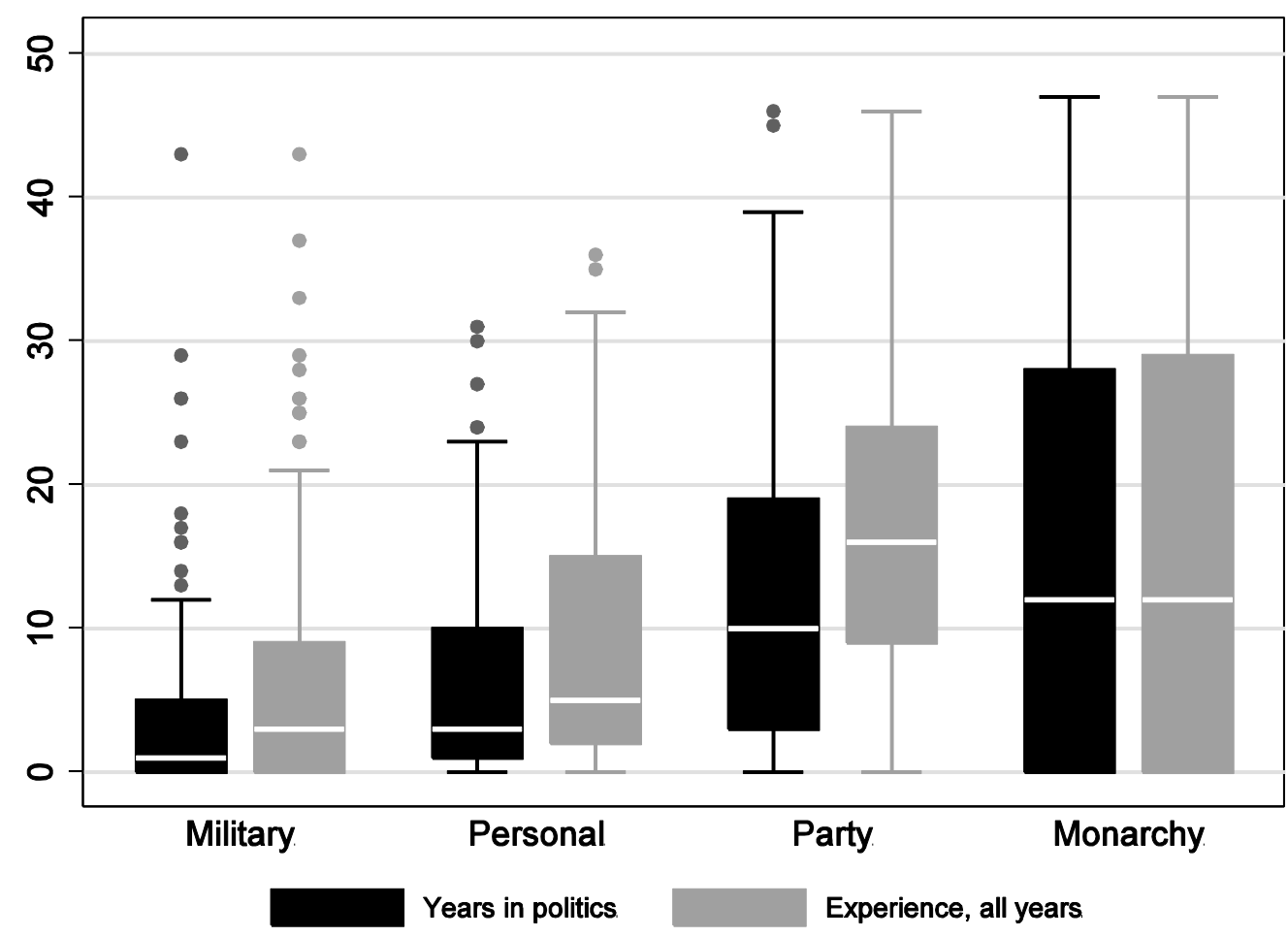

Figure 8. Political experience in dictatorship. Note: Vertical axis indicates years of experience prior to assuming office. The white line in the middle is the median number of years in each category.

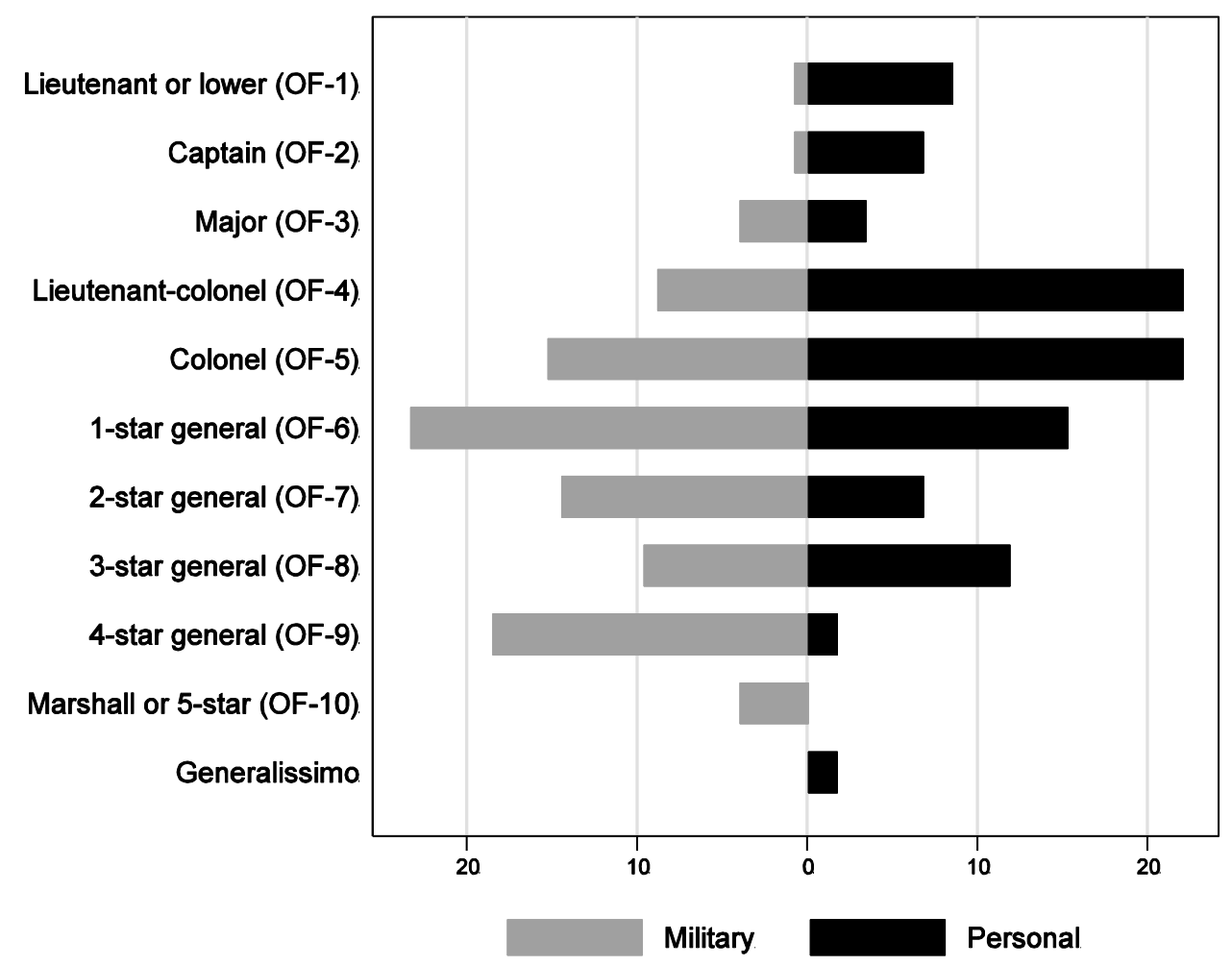

Figure 9. Military ranks of leaders in military and personal dictatorships. Note: Military ranks at the time of assuming office or retirement from the military, if prior to assuming office. Where leaders obtain a higher military rank while in office, such ranks are ignored. Categories report percentage of current or former military officers with particular ranks who assume office in two regime types. OF-1 to OF-10 are standardised NATO ranks. 
By way of illustration, Figure 9 displays differences in the military ranks of leaders in military and personal dictatorships at the time of assuming office. It gives evidence that in the majority of military regimes, it is close to impossible for those in lower ranks to seize power. Altogether, only 30 per cent of leaders in military regimes hold the rank of colonel or below, in contrast to 63 per cent of such leaders who hold ranks in personal regimes. Therefore, only 37 per cent of leaders with military ranks in personal regimes are generals at the time of assuming office, in contrast to 70 per cent in military regimes. Figure 9 indicates that elite coalitions that seize power to establish military regimes, or military leaders who succeed in office in already existing military regimes typically come from more institutionalised and hierarchical military organisations. In military regimes, those officers from the highest ranks become political leaders while lowerranked officers remain subordinates. In contrast, in less centralised militaries even lower-ranking officers have a chance at seizing power and becoming "military strongmen" themselves (Geddes, 1999; Weeks, 2012). For example, the military junta that overthrew President Mamadou Tandja of Niger in 2010 was headed by a mere platoon commander, Major Salou Djibo who was apparently outranked by several officers. ${ }^{16}$

\section{Conclusion: The Cursus Honorum and the Study of Political Leaders}

While studies exist that examined whether leaders in democracies and dictatorships have different personal and educational backgrounds (e.g., Besley \& ReynalQuerol, 2011; Bienen \& van de Walle, 1991; Dreher et al., 2009; Eulau \& Czudnowski, 1972; Pérez-Liñán, 2009), there are no systematic studies that examined leaders' careers and background across different types of dictatorships. This paper begins to fill the gap. Overall, leaders in party regimes, in terms of their careers and experience, have more in common with democratic leaders than with other dictators. Does political experience matter? While longer political careers in party dictatorships are determined by the hierarchical assignment of service and benefit (Svolik, 2012, p. 168), such longer political socialisation may in turn influence leaders' ability to work through existing rules and procedures and make policy compromises, which in turn may influence the observed policy outcomes in singleparty regimes. Also, Bienen and van de Walle (1991, pp. 51-52) acknowledge that leadership skills and ability to survive in office become evident only once leaders assume power, so that those leaders who survive lengthy periods in office can be attributed such skills ad hoc. One possible venue for future research is to examine whether lengthier political experience, or other

16 See Nossiter (2010). background traits and prior careers, contribute to the explanation of political survival in dictatorships. Likewise, we do not know whether dictators who succeed in overtaking their regimes and turning them into their own personal autocracies (Svolik, 2012, p. 56) all share particular leadership skills that may be related to their life experiences and background, or whether their success is driven by idiosyncratic factors. While the examination of leaders' effects is beyond the scope of this paper, further research may turn to the Cursus Honorum to study whether leaders' traits matter.

Even though studies exist that attempt to trace observable policy outcomes to leaders' background attributes and life experiences (Besley, Montalvo, \& Reynal-Querol, 2011; Dreher et al., 2009; Hayo \& Neumeier, 2014; Horowitz \& Stam, 2014), the effects of leaders' personal traits are however difficult to identify and separate from those of the effects of office occupied by such leaders, of their regimes, or overall context. As Blondel (1987, pp. 4-5) has remarked, "the impact of leaders depends on the environment...some have even said that leaders are prisoners of that environment, in that they can do only what the environment 'allows' them to do." The first hurdle in examining leaders' effects therefore is to distinguish between leaders' own effects and those of the offices they occupy (Baturo \& Elkink, 2014). Leaders' commands and policy preferences have also to be transmitted to, and implemented by their followers (Baturo \& Mikhaylov, 2013). Scholars must equally account for context, as crises and other events may dictate what leaders respond to, while customary practices dictate whether or not leaders should intervene at all (Blondel, 1987, p. 7). As an illustration, the lack of positive effects on the economy by leaders with a superior economics education may not necessarily render such leaders incompetent or their education unimportant; it may simply imply that they cannot, or decide not, to intervene in the economy.

In practice, scholars are more confident when they focus on policies and behaviours where leaders' own personal impact may be separated from that of other players or from the overall context, as opposed to outcomes largely determined by the environment, where the implementation of leaders' preferences may be impossible or outside of their control, such as inflation. Instead, for example, Horowitz and Stam (2014) examine the influence of leaders' personal traits on the likelihood of conflict initiation, while Baturo (2014) focuses on leaders' compliance with term limits. Indeed, while the vagaries of the economy are largely outside of their control, many leaders-especially those in dictatorshipshave more personal leverage over the direction of foreign policy, including war declaration; they also decide personally whether or not to prolong their time in office.

Overall, in non-democratic regimes, and especially in more personalised regimes, rulers typically have more policy discretion and fewer institutional con- 
straints. All things being equal, in less institutionalised settings with fewer veto players, i.e., dictatorships, the personal effects of leaders therefore should be easier to identify from those of other actors and contexts. Many comparativists find that personal dictatorships differ from party and military regimes in terms of their policies (e.g., Escribà-Folch \& Wright, 2015; Gandhi, 2008; Svolik, 2012; Weeks, 2012; Wright, 2008). As briefly discussed in the previous section, Figures 5-6 do not display dramatic differences between party and personal rulers. Still, the lack of average differences across regime types does not render leaders' traits unimportant. For instance, among dictatorships, personalist regimes experience the highest degree of policy volatility (Frantz \& Ezrow, 2011). Such observed volatility may be driven not only by the absence of constraints but also by a more pronounced random element, i.e., by within-regime type differences among different personal dictators in terms of their policy preferences and competence.

With the assistance of the Cursus Honorum, future studies may include such factors in their explanation. While there may be a debate as to whether leaders matter or if their effects may be identified at all, e.g., whether better education of leaders indeed accounts for policy competence (e.g., Besley \& Reynal-Querol, 2011), or not (e.g., Carnes \& Lupu, 2015), the data on leaders' educational attainment is necessary in order to have such a debate in the first place. This paper introduced the new and detailed data about personal characteristics and careers of political leaders. Other scholars may build on this data to study leadership. For instance, the data may be used to better understand the democratic breakdown or "revolving door" problem. Baturo (2014, pp. 187-211) examined compliance of presidents with term limits and found that while certain details, such as military background, being the father of a newly-independent nation or political outsider are associated with non-compliance, the effects of personal traits are inconsistent once regime selection effects are accounted for. Likewise, Baturo (in press) studied whether the availability of career options in retirement strengthened the rotation in office norm, while Baturo and Mikhaylov (2016) analysed whether the business careers of former leaders raise any concerns over democratic accountability.

\section{Acknowledgments}

Research for this project was supported by the Irish Council for Humanities and Social Sciences (now the Irish Research Council). The author would like to thank Declan Coogan and Peter McCrossan for their assistance in gathering the data.

\section{Conflict of Interests}

The author declares no conflict of interests.

\section{References}

Alexiadou, D. (2015). Ideologues, partisans and loyalists: Cabinet ministers and social welfare reform in parliamentary democracies. Comparative Political Studies, 48(8), 1051-1086.

Baturo, A. (2014). Democracy, dictatorship, and term limits. Ann Arbor, MI: Michigan University Press.

Baturo, A. (in press). Democracy, development, and career trajectories of former political leaders. Comparative Political Studies.

Baturo, A., \& Elkink, J. A. (2014). Office or officeholder? Regime deinstitutionalization and sources of individual political influence. Journal of Politics, 76(3), 859872.

Baturo, A., \& Mikhaylov, S. (2013). Life of Brian revisited: Assessing informational and non-informational leadership tools. Political Science Research and Method, 1(1), 139-157.

Baturo, A., \& Mikhaylov, S. (2016). Blair disease? Business careers of the former democratic heads of state and government. Public Choice, 166, 335-354.

Besley, T., Montalvo, J., \& Reynal-Querol, M. (2011). Do educated leaders matter? Economic Journal, 121 (554), 205-227.

Besley, T., \& Reynal-Querol, M. (2011). Do democracies select more educated leaders? American Political Science Review, 105(3), 552-566.

Bienen, H., \& van de Walle, N. V. (1991). Of time and power: Leadership duration in the modern world. Stanford, CA: Stanford University Press.

Blondel, J. (1987). Political leadership: Towards a general analysis. Beverly Hills, CA: Sage.

Bueno de Mesquita, B., Smith, A., Siverson, R., \& Morrow, J. (2003). The logic of political survival. Cambridge, MA: MIT Press.

Byman, D., \& Pollack, K. (2001). Let us now praise the great men: Bringing the statesmen back in. International Security, 25(4), 107-746.

Carnes, N., \& Lupu, N. (2015). What good is a college degree? Education and leader quality reconsidered. Journal of Politics, 78(1), 35-49.

Colgan, J. (2013). Domestic revolutionary leaders and international conflict. World Politics, 65(4), 656-690.

Dreher, A., Lein, S., Lamla, M., \& Somogyi, F. (2009). The impact of politicans' profession and education on reforms. Journal of Comparative Economics, 37(1), 169193.

Ellis, C. M., Horowitz, M., \& Stam, A. (2015). Introducing the LEAD data set. International Interactions, 41, 718-741.

Escribà-Folch, A., \& Wright, J. (2015). Foreign pressure and the politics of autocratic survival. Oxford: Oxford University Press.

Eulau, H., \& Czudnowski, M. (1972). Elite recruitment in democratic polities. London: Sage.

Frantz, E., \& Ezrow, N. (2011). The politics of dictator- 
ship: Institutions and outcomes in authoritarian regimes. Lynne Rienner.

Frantz, E., \& Kendall-Taylor, A. (2014). A dictator's toolkit: Understanding how cooptation affects repression in autocracies. Journal of Peace Research, 51(3), 332-346.

Gandhi, J. (2008). Political institutions under dictatorship. Cambridge, New York: Cambridge University Press.

Geddes, B. (1999). What do we know about democratization after twenty years? Annual Review of Political Science, 2, 115-144.

Geddes, B., Wright, J., \& Frantz, E. (2012). New data on autocratic breakdown and regime transitions. Dataset.

Gerring, J., Oncel, E., Morrison, K., \& Keefer, P. (2014, August). The global leadership project: A comprehensive database of political elites. Presented at the 2014 Annual Meeting of the American Political Science Association, Washington, DC.

Gleditsch, N. P., Wallensteen, P., Eriksson, M., Sollenberg, M., \& Strand, H. (2002). Armed conflict 19462001: A new dataset. Journal of Peace Research, 25, 393-413.

Goemans, H. (2008). Which way out? The manner and consequences of losing office. Journal of Conflict Resolution, 53(6), 771-794.

Goemans, H., Gleditsch, K., \& Chiozza, G. (2009). Introducing Archigos: A data set of political leaders. Journal of Peace Research, 46, 269-283.

Goodman, M. (1997). The roman world: 44 BC-AD 180. London: Routledge.

Hayo, B., \& Neumeier, F. (2014). Political leaders' socioeconomic background and fiscal performance in Germany. European Journal of Political Economy, 34, 184-205.

Heston, A., Summers, R., \& Aten, B. (2012). Penn world table version 7.1. Center for International Comparisons of Production, Income and Prices at the University of Pennsylvania.

Horowitz, M., \& Stam, A. (2014). How prior military experience influences the future militarized behavior of leaders. International Organization, 68(3), 527-559.

Iqbal, Z., \& Zorn, C. (2008). The political consequences of assassination. Journal of Conflict Resolution, 20, 1-16.

Klingemann, H. -D. (1966). Keine saeulen der demokratie: Ueber die haltung der gebildeten zur NPD. Akut, 19(29-30), 6-9.

Kudamatsu, M. (2012). Has democratization reduced infant mortality in sub-Saharan Africa? Evidence from micro data. Journal of the European Economic Association, 10(6), 1294-1317.

Lentz, H. (1994). Heads of states and governments: $A$ worldwide encyclopedia of over 2,300 leaders, 1945 through 1992. London: McFarland and Co.

Linz, J. (1994). Presidential or parliamentary democracy: Does it make a difference? In J. Linz \& A. Valenzuela
(Eds.), The failure of presidential democracy: The case of Latin America (pp. 3-87). Baltimore: Johns Hopkins University Press.

Ludwig, A. (2002). King of the mountain: The nature of political leadership. Lexington: University Press of Kentucky.

Marshall, M., \& Jaggers, K. (2011). Political regime characteristics and transitions, 1800-2010, dataset users' manual, polity IV project. Maryland, MD: University of Maryland, College Park.

McDermott, R. (2007). Presidential leadership, illness, and decision making. Cambridge: Cambridge University Press.

Nossiter, A. (2010, February 19). Niger capital is calm after coup. The New York Times. Retrieved from http:// www.nytimes.com/2010/02/20/world/africa/20nige r.html?_r=0

Pérez-Liñán, A. (2009). La renovación de las elites presidenciales en América Latina, 1900-2007. Sistema, 208-209, 37-53.

Pettibone, C. (2009). Organization and order of battle of militaries in World War II: Union of Soviet Socialist Republics. Bloomington, ID: Trafford Publishing.

Przeworski, A., Alvarez, M., Cheibub, J., \& Limongi, F. (2000). Democracy and development: Political institutions and well-being in the world, 1950-1990. Cambridge, New York: Cambridge University Press.

Putnam, R. (1973). The beliefs of politicians: Ideology, conflict, and democracy in Britain and Italy. New Haven: Yale University Press.

Skidmore, T. (1988). The politics of military rule in Brazil, 1964-85. New York: Oxford University Press.

Stasavage, D. (2005). Democracy and education spending in Africa. American Journal of Political Science, 49(2), 343-358.

Svolik, M. (2012). The politics of authoritarian rule. Cambridge: Cambridge University Press.

Treisman, D. (2000). The causes of corruption: A crossnational study. Journal of Public Economics, 76(3), 399-457.

Tullock, G. (1987). Autocracy. Boston: Kluwer Academic Publishers.

Weeks, J. (2012). Strongmen and straw men: Authoritarian regimes and the initiation of international conflict. American Political Science Review, 106(2), 326346.

Wintrobe, R. (1998). The political economy of dictatorship. Cambridge, New York: Cambridge University Press.

Wright, J. (2008). Do authoritarian institutions constrain? How legislatures affect economic growth and investment. American Journal of Political Science, 52(2), 322-343.

Zarate, R. O. (2011). Biografıas líderes políticos. CIDOB. Retrieved from http://www.cidob.org/biografias_lid eres_politicos 


\section{About the Author}

Alexander Baturo is Lecturer in Comparative Politics at Dublin City University. He works on various aspects of comparative democratization and leadership, particularly presidentialism and personalism, among other things. He has published in journals such as Journal of Politics, British Journal of Political Science, and Public Choice, among others. His book, Democracy, Dictatorship, and Term Limits, was published by University of Michigan Press in 2014 and won the 2015 Brian Farrell prize from the Political Science Association of Ireland. 